ppi $201502 Z U 4645$

Esta publicación científica en formato digital es continuidad de la revista impresa ISSN-Versión Impresa 0798-1406 / ISSN-Versión on line 2542-3185Depósito legal pp $197402 Z$ U34

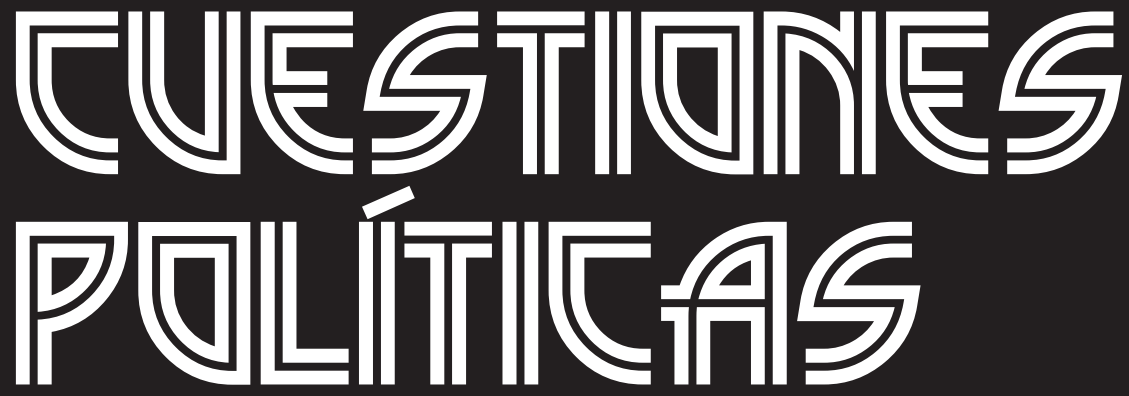

Instituto de Estudios Políticos y Derecho Público "Dr. Humberto J. La Roche" de la Facultad de Ciencias Jurídicas y Políticas de la Universidad del Zulia Maracaibo, Venezuela


$N^{\circ}$ Especial 1era Parte 2020 


\title{
Educational processes of training, retraining and advanced training of private detectives in Ukraine
}

\author{
DOI: https://doi.org/10.46398/cuestpol.38e.28
}

\author{
Kyslyi Anatolii * \\ Pysmenna Mariia ** \\ Kolomoiets Oleksandr *** \\ Volobuieva Olena $* * * *$ \\ Bezusyi Vadym *****
}

\begin{abstract}
The aim of the article was to carry out a retrospective analysis of the legal acts on the legalization of private detective activities in Ukraine and, at the same time, consider the characteristics of training, retraining and advanced training of private detectives in order to to further improve legislation in this area. The subject of the study is essentially the process of training, retraining and advanced training of private detectives in Ukraine. During the research, the following scientific methods were used: dialectical method, methods of synthesis and analysis, methods of induction and deduction, statistical method, historical and legal and formal and legal methods. The peculiarities of the Law of Ukraine "On the Activity of Private Detective (Search)" were considered, its advantages and disadvantages were described. By way of conclusion, he emphasizes that the existing legal education system, introduced in civil educational institutions, is not adequate for the training of private detectives. For these and other political and legal reasons, the need to
\end{abstract}

* Doctor of Law, Professor, Director of the Educational and Scientific Law Institute named after the Prince Vladimir the Great of Interregional Academy of Personnel Management, Ukraine. ORCID ID: https://orcid.org/oooo-0oo2-4152-9539. Email: iapm@iapm.edu.ua

** Doctor of Economics, Associate Professor, Dean of the Faculty of Management, Professor of the Department of Management, Economics and Tourism of Flying Academy of the National Aviation University, Ukraine. ORCID ID: https://orcid.org/oooo-0003-4509-8147. Email: mari. pismennaya.83@ukr.net

*** Ph.D in Law, Associate Professor, Leading specialist in the organization of scientific work of the department for ensuring the activities of Kirovohrad Scientific Research Forensic Center of the Ministry of Internal Affairs of Ukraine, Ukraine. ORCID ID: https://orcid.org/oooo-00o3-2966-7506. Email: kirovograd@dndekc.mvs.gov.ua

****PhD in Law, Associate Professor, Head of the Department of Criminal Law Disciplines and Forensic Science of the Faculty no. 1 of Donetsk Law Institute of the Ministry of Internal Affairs of Ukraine, Ukraine. ORCID ID: https://orcid.org/oooo-0002-8601-4344. Email: postmaster@dli.donetsk.ua

*****Doctor of Legal Sciences, Associate Professor, Professor of the Department of Legal Support of Economic Activity of Faculty № 6 of Kharkiv National University of Internal Affairs. ORCID ID: https://orcid.org/oooo-0003-4209-5709. E-mail: odin.univd@gmail.com 


\section{Kyslyi Anatolii, Pysmenna Mariia, Kolomoiets Oleksandr, Volobuieva Olena y Bezusyi Vadym Educational processes of training, retraining and advanced training of private detectives in

train private detectives in the system of higher education institutions with specific learning conditions in the heat of the requirements imposed by reality itself is argued.

Keywords: private detective; private detective agencies; vocational training; recycling; advanced training.

\section{Procesos educativos de formación, reciclaje y formación avanzada de detectives privados en Ucrania}

\section{Resumen}

El objetivo del artículo fue realizar un análisis retrospectivo de los actos jurídicos sobre la legalización de las actividades de detective privado en Ucrania y, al mismo tiempo, considerar las características de la formación, el reciclaje y la formación avanzada de los detectives privados con el fin de mejorar aún más la legislación en esta área. El tema del estudio es esencialmente el proceso de formación, reciclaje y formación avanzada de detectives privados en Ucrania. En el curso de la investigación se utilizaron los siguientes métodos científicos: método dialéctico, métodos de síntesis y análisis, métodos de inducción y deducción, método estadístico, métodos históricos y legales y formales y legales. Se consideraron las peculiaridades de la Ley de Ucrania «Sobre la actividad de detective privado (búsqueda)», se describieron sus ventajas y desventajas. A modo de conclusión desataca que el sistema de educación jurídica existente, introducido en las instituciones educativas civiles, no es adecuado para la formación de detectives privados. Por estas y otras razones políticas y jurídicas, se argumenta la necesidad de formar detectives privados en el sistema de instituciones de educación superior con condiciones específicas de aprendizaje al calor de los requerimientos que impone la propia realidad.

Palabras clave: detective privado; agencias de detectives privados; formación profesional; reciclaje; formación avanzada.

\section{Introduction}

Ukraine is on the path of significant changes at the current stage of its development: the structure of economic relations is changing, new subjects of property and political activity are being formed, basic values, living arrangements are being transformed, the way of life and traditions are changing (Medvedev, 2014, p. 235). Therefore, radical socio and 
economic transformations that have taken place over the past decade led to both positive and negative changes in modern Ukrainian society (Pavlenko et al, 2017). The development of welfare State in the context of legal European integration implies that a person, his life and health, honor and dignity are recognized in Ukraine as the highest social value and their protection is a priority of the criminal law policy of the country. However, the construction of civil society and democratic State governed by the rule of law in accordance with the European standards is significantly hampered by a serious aggravation of the criminal situation, an increase in organized crime (Nykyforchuk et al, 2017).

The Verkhovna Rada of Ukraine notes that the state of observance of the rule of law in ensuring human rights and freedoms in the work of law enforcement agencies does not comply with the Constitution of Ukraine; the level of crime in the country threatens Ukraine's national security. The criminalz situation in the country is difficult, tense and unstable in terms of level, content and negative consequences. From year to year, organized crime and the number of crimes against life, health and property of citizens are growing. Organized criminal groups are not detected at the stage of their creation, so they can operate on the territory of the State from two to five years.

Civil society institutions can provide necessary resources to combat illegal encroachment through the privatization of law enforcement. This process is noticeable in the legislation and practice of many countries, where the development of private detective agencies (security firms, security services and various public law enforcement agencies) is encouraged. It is the set of such institutions, which may have some of the purely law enforcement functions and characteristics, that forms the basis of the non-state law enforcement system (Yurko, 2017). Private detective (search) activity is recognized at the State level in most countries of the world, is regulated by law and is optimally used to increase the ability of citizens and legal entities to protect their legal rights and interests (Bezzub, 2017).

Ukraine has been building a law-based State on the example of the European community, in which an individual, his life and health, honor and dignity, inviolability and security are the greatest social values. Many countries have recognized and regulated private detective activities at the state level to provide more opportunities for individuals and legal entities for protection of their legal rights and interests. Considering all the factors, the activity of private detective agencies or private detectives is quite new in Ukraine, although their popularity is only growing every year (Gryshko, 2018).

Currently, the services of private detective agencies and detectives are in demand not only among individuals but also government agencies and institutions. Thus, the activities of private detectives are recognized as an 
Kyslyi Anatolii, Pysmenna Mariia, Kolomoiets Oleksandr, Volobuieva Olena y Bezusyi Vadym Educational processes of training, retraining and advanced training of private detectives in

auxiliary and even integral part of the work of law enforcement agencies of Ukraine. Thus, in connection with the introduction of private detective work in Ukraine there are a number of questions and problems, namely: what should be the education of a private detective and who will provide training, preparation, retraining and advanced training of such persons, which determined the relevance of the chosen topic.

\section{Materials and methods}

Methodological basis of the study is a set of general philosophical, scientific, and special methods of cognition, the choice of which is due to scientific and applied expediency. Dialectical method allowed to study the object and subject of research in their development and interaction. The method of analysis was used to fragment the complex phenomenon of detective activity in Ukraine into simpler elements, which significantly affected the content and structure of the subsections of the article. The method of induction helped to analyze the problems related to the legal status of private detective in Ukraine.

Deductive method contributed to the sequence of presentation of the material and influenced the overall structure of the content of the research. The method of synthesis was used to study theoretical approaches to the institution of private detectives in Ukraine and to generalize the main provisions of the research, which allowed to expand the existing ideas about theoretical foundations of non-state law enforcement. Statistical method was applied to analyze statistical data on the level of confidence of Ukrainian people in the judiciary and law enforcement agencies. Historical and legal method helped in the study of the genesis of non-state law enforcement during the main stages of Ukraine's development. Formal and legal method contributed to the analysis of legal acts, which regulate the issue under consideration.

The security services of enterprises in the aspect of non-state law enforcement were studied by Mak-Mak (2003) in his monograph "Security services of enterprises as the subject of private law enforcement". He tends to consider security services as independent subjects of non-state law enforcement because their functions specify general law enforcement functions and is also a supporter of recognizing security services as independent subjects of law in the form of an autonomous non-profit organization.

Russian author Kvasha (2000) united private detective and security activities under the term "private police". This approach is found in the literature but is questionable. Private police in the United States and some 
European countries are generally security agencies that provide public order and security services on the basis of agreements with public authorities and local governments. Such companies can really use the word "police" in their official name.

Sachavo (2006) monograph "Administrative and legal bases of activity of private security structures and their interaction with the police of Ukraine" also attracts attention because of its historical and legal analysis. The author disputes the idea of fundamentally new nature of private security activities in domestic law enforcement practice and even argues that the emergence of private security in Ukraine in its modern form occurred earlier than in other countries (France, USA, Japan, Germany, etc.).

The tradition of considering the activities of security agencies and private detective agencies in the context of ensuring economic security of entrepreneur activity is quite common in Ukraine. For example, detective and security activities are considered as tools to ensure business security, combating unlawful encroachments on the interests of enterprises under modern market conditions in the textbook of Bondarchuk "Business security: organizational and legal bases" (Bondarchuk, 2008).

The features of private detective activities in separate countries were investigated by Tameryan et al. (Great Britain) (2018), Matiukhina (Great Britain) (2001), Matiukhina (USA) (2013), etc.

\section{Results and Discussions}

The priority of human rights and freedoms in decision-making by public authorities and local governments determine the purpose of their activities. To ensure the effective realization of the National Strategy for Human Rights, which was adopted in order to improve the establishment and protection of human and civil rights and freedoms in Ukraine, and the Action Plan for its implementation, the Ukrainian Helsinki Human Rights Union, with the support of the Commissioner for Human Rights, established a Public Monitoring Platform (Motuz, 2011).

In this regard, today there is a question of legalization of nongovernmental organizations and independent experts to engage in private detective work in Ukraine, which will primarily be aimed at ensuring the rights and freedoms of man and citizen. This type of activity had been not officially recognized and regulated in Ukraine for a long time, although in fact not only individuals but also legal entities had productively been engaged in private detective activity. According to unofficial data, several thousand private detectives and private detective agencies are now operating in all regions of Ukraine, and their services are in great demand among business, politicians, and lawyers (Motuz, 2011). 
Kyslyi Anatolii, Pysmenna Mariia, Kolomoiets Oleksandr, Volobuieva Olena y Bezusyi Vadym Educational processes of training, retraining and advanced training of private detectives in

Ukraine is one of the few countries in Europe where the activities of private detectives are illegal. Private detectives in our country work under the guise of security or information-analytical agencies. They often use journalists' IDs to conduct their investigations. In general, they are guided by the principle "what is not forbidden is allowed".

According to the All-Ukrainian Association of Private Detectives, the number of search agencies in Ukraine has increased tenfold to 500 over the past two years, and 15\% of Ukrainians have approached them for various reasons (Sarana, 2014). According to unofficial figures, there are about a thousand private detective agencies and private detectives who have successfully disguised themselves as law firms providing security or technical services. These services are used by politicians, lawyers, businessmen. A firm can offer protection from wiretapping or industrial espionage, but in fact it collects information about competitors at the request of a commercial syndicate.

Relatively low level of development of security activities in Ukraine is indicated by the existence of hundreds of small security structures, which still often provide low-quality services. The main reason for this is that the requirements for obtaining a license to carry out security activities are not strict enough. Firstly, those wishing to obtain a security license do not need to have a bank guarantee confirming the financial security of the entity's liability. Secondly, there are no strict requirements for the level of material and technical base and the availability of round-the-clock operative information centre. Thirdly, at the time of establishing a new company, it is not necessary to have qualified staff. As a result, the Ukrainian market is oversaturated with security entities that provide low-quality services, and the security profession is considered temporary one (Yurko, 2017).

After the events of 2014, the citizens of Ukraine express full mistrust to the law enforcement system. It should be emphasized that the main reason for the current large-scale reform of law enforcement agencies and the introduction of private detectives was the distrust of the people of Ukraine, namely to inaction and unprofessionalism of the former in the implementation of the work within their powers. 30\% of respondents support the statement that the "police state" is being built in Ukraine, while $36 \%$ disagree with it. At the same time, 34\% were undecided about their attitude (Sociological group "Rating” 2012).

According to a survey conducted by the Dragon Capital Investment Company (Kyiv) and the European Business Association, there is widespread corruption in Ukraine and a lack of confidence in the judiciary and law enforcement agencies. As reported in a joint press release of the organizations, the respondents rated the obstacles on a 10-point scale of importance at 8.5 and 7.5 points, respectively. Such factor as monopolization of markets and the seizure of power by the oligarchs is in 
$3^{\text {rd }}$ place in the ranking (5.9 points), while the military conflict with Russia and unpredictable exchange rate (5.6 points) fell to 4 th and 5 th positions, respectively. Repressive actions of law enforcement agencies occupy the 6th position in the ranking (4.6 points). This is due to mass cases of illegal actions of the prosecutor's office, the Security Service, and the police. Other positions include constant changes in legal regulation, complex tax administration, and currency restrictions (Center of Economic Strategy, 2017).

In December 2017, volunteer organizations (+ 37\%), the Armed Forces of Ukraine (+ 37\%), the Church (+ 25\%), and public organizations $(+4 \%)$ achieved the best level of trust among social institutions.

Instead, the other institutions whose credibility was assessed have a negative balance of trust. Among the leaders of distrust are courts (-75\%) and the prosecutor's office $(-74 \%)$. Other social institutions also have a negative balance of trust / distrust: police $(-46 \%)$, Security Service of Ukraine $(-26.5 \%)$, trade unions $(-25 \%)$, Western media $(-22 \%)$, patrol police $(-19 \%)$, ombudsman $(-17 \%)$, National Anti-Corruption Bureau of Ukraine $(-12 \%)$, local governments $(-12 \%)$, Ukrainian media $(-6 \%)$. The balance of trust / distrust in all institutions has either hardly changed or deteriorated compared to December 2016. The biggest deterioration is in the patrol police (negative balance increased by 24\%) (Ilko Kucheriv Democratic Initiatives Foundation, 2017).

Thus, we support the opinion that the analysis of the attitude of the population to law enforcement agencies, the relationship between trust and distrust is a significant aspect in the general study of the prevailing mood in society. After all, in fact, this is a comprehensive indicator, on the basis of which it is possible to draw conclusions not only directly about the population's assessment of the work of law enforcement system, but also about larger trends.

Firstly, the trust in law enforcement agencies is evidence of the effectiveness of their work from the perspective of ordinary citizens of the country and the confirmation of public satisfaction with the activities of these structures. The opposite situation (when distrust prevails over trust) testifies, first of all, to the non-fulfillment or incomplete fulfillment of the functions assigned to them in this society.

Secondly, in a broader sense, the level of public confidence in law enforcement agencies and courts can be considered as one of the indicators of the development of the rule of law in Ukraine, the existence of problems in the field of compliance with the rule of law. This is due to the fact that law enforcement agencies and courts are the bodies that are created to protect the rights and freedoms of an individual and a citizen, and the high level of distrust in them, in view of this, indirectly indicates a violation of the rule of law. 
Kyslyi Anatolii, Pysmenna Mariia, Kolomoiets Oleksandr, Volobuieva Olena y Bezusyi Vadym Educational processes of training, retraining and advanced training of private detectives in

Thirdly, confidence in law enforcement is also a component of the overall democracy of society and the system of government in particular. It is implied that in a society where democratic standards are fully respected; the law enforcement and judicial system operate transparently and cannot be influenced from the outside.

Having analyzed a number of reasons, which are different in nature and founded by various institutions (organizations), it should be stated that the implementation of institution of private detectives to ensure the constitutional guarantees of an individual and citizen to protect their legal rights and interests will effectively promote private detective (investigative) activities in Ukraine.

There are a number of draft laws from 2000 to 2017 on regulation on private detective activities, developed by different authors, but which, however, have not received relevant legislative support.

In particular, in 2005 private detective activity (which in fact has already emerged in our country and was carried out spontaneously in its various regions) was actually brought closer to legalization. This happened on January 12, 2005 during the discussion in the Parliament of the package of bills "On the Security Service of Business Entities and Other Legal Entities", "On Security Activities" and "On Private Detective Activities" (no. 5380), as well as an alternative bill "On Private Detective Activities" (no. 5380-1), submitted by other representatives of the Parliament. It was at this plenary session of the Verkhovna Rada of Ukraine that the deputies agreed on the need to legalize the activities of private security guards - detectives who were already actually working (Pidiukov, 2016: 168).

Domestic lawmakers returned to this issue only two and a half years in a row, when on June 26, 2007 the Draft Law "On Private Detective Activity" was registered in the Verkhovna Rada of Ukraine (no. 3727). The author of the document - Serhiy Gusarov, Chairman of the Subcommittee of the Verkhovna Rada of Ukraine on Legislative Support and Parliamentary Control over the Activities of Internal Affairs Bodies - also stressed the need to adopt it, as "such relations have already been developed in the country" (Pidiukov, 2016: 167).

Even after that, on February 25, 2008, December 13, 2012, and December 28,2015 , three more bills on private detectives and detective (investigative) activities were registered in the Verkhovna Rada of Ukraine (no. 2120, 1093 and 3726, respectively). And only the last of them, in the end, was adopted in the first reading at a meeting held on April 19, 2016 (Pidiukov, 2016).

The bill proposed in 2013 by the All-Ukrainian Association of Private Detectives has been far from ideal. From November 2015 to February 2016, it was finalized in the legal department of Private Police Company LLC and was hastily handed over to the experts to bring its text in line with 
the requirements for documents submitted to the Verkhovna Rada. The amended text of the draft Law of the All-Ukrainian Association of Private Detectives included the opinions of practitioners - private detectives, business security specialists, other persons who are relevant to the implementation of this Law (Razumkov Center, 2016).

New attempts to regulate the area of private detective activities were undertaken in 2015 - 2016; but since the end of 2015, this issue of came to the fore again. On December 28, 2015, a new Draft Law on private detective (search) activity no. 3726 was registered (Motuz, 2011).

The features of this project: a) $70 \%$ of its text is borrowed without permission from the project proposed in 2013 by the All-Ukrainian Association of Private Detectives; b) the remaining 30\% of the Draft Law are taken from various not very progressive bills and inserted into the document, which destroyed not only the content proposed by the practitioners, but also continues to increase the possibility of corruption and the emergence of a number of by-laws. On April 13, 2016, at the second attempt, this bill was passed in the first reading (Motuz, 2011).

On April 13, 2017, more than twenty years of history of legalization of private search in Ukraine ended with the adoption of the Law of Ukraine "On Private Detective (Investigative) Activity" and a new stage in the development of the private detective profession began (Draft Law of Ukraine, 2015). However, on June 07, 2017 the President of Ukraine vetoed it. It was noted that the law formed a list of permitted types of private detective services without taking into account the requirements of a number of legislative acts of Ukraine.

Thus, we considered the current state of detective activity, the reasons that did not contribute to the development of such activity, a retrospective analysis of the formation of private detective (search) activity. It turns out to be expedient to move on to the problem of private detective education, training, preparation and retraining of such persons.

Having a direct impact on crime prevention, detective agencies have a special place in the group of non-state law enforcement agencies. Given that the institution of private detectives is only developing, it would be appropriate, in addition to the legislative consolidation of the activity itself, to ensure a quality system of detective training and interaction between private and public law enforcement agencies.

Thus, we will consider the main issues of training, education, retraining and advanced training of private detectives, enshrined in the Draft Law of Ukraine "On private detective (investigative) activities". It should be noted that a significant part concerns one of the key issues - the training of future private detectives, which requires urgent scientific analysis. 
Kyslyi Anatolii, Pysmenna Mariia, Kolomoiets Oleksandr, Volobuieva Olena y Bezusyi Vadym Educational processes of training, retraining and advanced training of private detectives in 430 Ukraine

The bill contains a list of requirements that a private detective must meet. A private detective can be a citizen of Ukraine who has reached 21, speaks State language, obtained higher legal education or work experience in operational units or pre-trial investigation bodies for at least three years, has undergone training for private detective (investigation) activities and received a certificate confirming the right to be engaged in private detective (investigative) activities (Article 5 of the Draft Law of Ukraine "On private detective (investigative) activities".

Article 8 (Issuance of a certificate of the right to engage in private detective (search) activity) states that to obtain a certificate confirming the right to be engaged in private detective (investigative) activities, a private detective submits such documents to the authorized body as duly certified copies of documents confirming the person's citizenship, higher legal education, relevant training or work experience, work experience in operational units or pre-trial investigation bodies. Article 14 "Responsibilities of a subjects of private detective (search) activity" notes that subjects of private detective (search) activity are obliged: to undergo retraining and advanced training.

Article 18 "Training of Private Detectives" defines that the procedure for training, retraining and advanced training of private detectives is approved by the National Police of Ukraine, taking into account the provisions of this Law; relevant agreements for the training, retraining and advanced training of persons engaged in private detective (investigative) activities may be concluded with higher education institutions, regardless of their form of ownership; development of training programs provided for in part two of this article is carried out in the manner prescribed by the central executive body that ensures the formation and implementation of State policy in education and science, in coordination with the Ministry of Internal Affairs of Ukraine, National Police of Ukraine, Ministry of Health Ukraine and the Ministry of Finance of Ukraine; the central body of executive power, which ensures the formation and implementation of State policy in the area of education and science, in the manner prescribed by law, approves the requirements for the content of training programs for the persons engaged in private detective (investigative) activities.

The persons who carry out private detective (search) activities and have been trained according to training, retraining and advanced training programs, receive a document of a higher educational institution of the established standard; subjects of private detective (search) activity who have not undergone training, retraining or advanced training are prohibited from engaging in private detective (search) activity.

I. Bezzub emphasizes that the provisions of the Draft Law of Ukraine "On Private Detective (Investigative) Activities" on education and training contains do no satisfy a number of professionals who emphasize the requirement for compulsory higher legal education, which should be 
replaced by simply higher education, since future detectives still have to undergo appropriate training (Bezzub, 2017). In our opinion, it is unnecessary to require legal education or experience in law enforcement from a candidate for detectives, because representatives of other professions can successfully cope with such work if they just have search and analytical skills. Thus, higher legal education can be replaced by higher education in any field, because future detectives will undergo appropriate training.

We do not support this position, so we argue it. With regard to the training of private detectives by civil universities of public and private ownership, we would like to mention the statement of professor Venediktov on the significant difference between training in departmental (system of the Ministry of Internal Affairs of Ukraine) and civilian educational institutions and on the absolute inability of civilian universities to provide training of appropriate professional level and quality (Zozulya, 2008).

Thus, it should be noted that the existing system of legal education, introduced in civilian educational institutions, is not suitable for the training of private detectives because of the following reasons:

1. Civilian educational institutions do not set the goal of training specialists in detective activity; therefore, do not take into account its specifics. They mostly train specialists of the so-called broad profile in the specialty of law.

2. Despite the specifics of professional training of legal personnel, which is due to the peculiarities of the content of their subsequent activities, admission to the law faculties and law universities does not differ from admission to other faculties or other higher education institutions. The main criterion for selecting potential legal professionals is the successful results of an external independent evaluation. This criterion is undoubtedly necessary, but its application does not reveal such necessary qualities for a future private detective as honesty, morality, steadfastness and psychological endurance. These qualities are not properly reflected in the documents submitted by the applicant (Pavlenko et al, 2017).

Psychological training is becoming quite relevant under modern conditions in various fields of psychological knowledge. This is explained primarily by a number of objective and subjective difficulties experienced by employees in hazardous occupations in emergencies during the performance of their professional duties. This is especially true for those activities that are saturated with various extreme situations. Such activities include the professional activities of private detectives (Mohilevskyi et al, 2017).

3. Educational programs in civilian educational institutions do not take into account practical training, prefer theory and are detached from practice. Educational programs do not include the disciplines, which are 


\section{Kyslyi Anatolii, Pysmenna Mariia, Kolomoiets Oleksandr, Volobuieva Olena y Bezusyi Vadym Educational processes of training, retraining and advanced training of private detectives in 432 Ukraine}

necessary for the future private detective, as: "Combat training", "Search activity", "Special equipment", "Special tactics". Even physical training at law faculties and law schools is conducted according to a general program that does not take into account the specifics of the future activities of private detectives.

4. Not all students of law faculties and law universities can undergo internships in the departments of the National Police of Ukraine. The practitioners are not interested in guiding the practice of students of civilian universities.

5. Some of the civilian educational institutions train specialists with legal education both in full-time and part-time education. It should be noted that the training of investigators, operatives and other specialists, who can later become private detectives, requires taking into account the specifics of their activities.

6. Civilian educational institutions produce the graduates who, for the most part, are unable to adapt to the practical unit and perform their duties effectively - it takes some time to fully prepare them for practical activities (Hrytsia, 2008).

Thus, departmental universities of the Ministry of Internal Affairs, unlike many other civilian universities, not only provide the process of theoretical training, but pay great attention to practical training, both law enforcement and private detectives, who will represent the Ministry of Internal Affairs in the near future. A specialist will not "be able to assess a situation in which he is likely to be influenced by some of his own prejudices and emotions" without such combination of theory and practice (Rogers, 1963). Besides, we support the idea of Khaertdinov et al. (2019, p. 58) that successful training of the officers is impossible without firm conviction in the strength and justice of the State, stable positive dynamics in the formation of positive social attitudes, value orientations and value priorities.

\section{Conclusion}

Ukraine, as a European State, is aware of the urgency of further improvement and development of new approaches in the area of public policy on the introduction of private detective (search) activities and stresses the importance of educational training of private detectives because ensuring the protection of human and civil rights and freedoms is one of the main activities of the State. In any case, the legalization of private detectives is necessary, because Ukrainians must be able to choose whom to trust their security. 
The adoption of the Law of Ukraine "On Private Detective (Investigative) Activity" is necessary for our State, because it will legalize and bring out of the shadows the market of detective services, the demand for which will only grow every year. Besides, the rules established by law provide the entities, which want to engage in this activity, the guarantees that protect the rights and interests of persons represented by a private detective. It should be noted that private detectives can significantly help their clients, given the low level of training of some law enforcement officers, as well as large workload of enforcement system.

\section{Bibliographic References}

BEZZUB, Iryna. 2017. "Private detective activity: Ukrainian realities and foreign experience" In: Social Communication Research Center. Available online. In: http://nbuviap.gov.ua/index.php?option=com_content\&v iew=article\&id=2930:privatna-detektivna-diyalnist-ukrajinski-realijita-zarubizhnij-dosvid\&catid $=8 \&$ Itemid $=350$. Date of consultation: 19/07/2020.

BONDARCHUK, Yurii. 2008. Business security: organizational and legal bases: textbook. Kyiv, Ukraine. Publishing House "Skif".

CENTER OF ECONOMIC STRATEGY. 2016. Corruption and lack of trust in the judiciary in Ukraine are the largest obstacles for foreign investors. Available online. In: https://ces.org.ua/koruptsiia-ta-nedovira-dosudovoi-systemy-v-ukraini/. Date of consultation: 22/07/2020.

DRAFT LAW OF UKRAINE. 2015. On Private Detective (Search) Activity of December 28, 2015 no. 3726. Available online. In: http://search. ligazakon.ua/l_doc2.nsf/link1/JH2VIooP.html. Date of consultation: 25/07/2020.

GRYSHKO, Viktoria. 2018. "Problems of implementation of the Law "On private detective (search) activity" in Ukraine based on foreign experience" In: Legal scientific electronic journal, Vol. 1, No. 1, pp, 197-199.

HRYTSIA, Tetiana. 2002. "Value of departmental education for training of police officers of Ukraine" In: Law and Security, Vol. 8, No. 4, pp. 55-59.

ILKO KUCHERIV DEMOCRATIC INITIATIVES FOUNDATION. 2017. Public opinion: electoral ratings and trust ratings: survey. Available online. In: http://dif.org.ua/article/reytingijfojseojoej8567547. Date of consultation: 19/07/2020. 
Kyslyi Anatolii, Pysmenna Mariia, Kolomoiets Oleksandr, Volobuieva Olena y Bezusyi Vadym Educational processes of training, retraining and advanced training of private detectives in

KHAERTDINOV, Ilgizar, SHVETSOV, Alexander, KUZNETSOV, Alexander, ARYABKINA, Irina and DONINA, Olga. 2019. "Vocational training of air force officers: Methodology of Axiological Approach" In: Amazonia Investiga, Vol. 8, Num. 19, pp. $57-71$.

KVASHA, Liliana. 2000. Law enforcement agencies of the Russian Federation. Part 2: Bodies that ensure public safety, protection of public order and fight crime: textbook. Moscow, Russia. CheRo-Kontur.

MAK-MAK, Vasyl. 2003. Security service of the enterprise as a subject of private law enforcement: a monograph. PhD dissertation. Moscow, Russia. Academy of Management of the Ministry of Internal Affairs of Russia.

MATIUKHINA, Nataliia. 2001. Police of Great Britain: modern tendencies of development and management: monograph. Charkiv, Ukraine. Consum.

MATIUKHINA, Nataliia. 2013. US private security sector: ways of development and realities of the present: monograph. Charkiv, Ukraine. Yurait.

MEDVEDIEV, Oleh. 2014. "Ethnic crime in the gypsy environment" In: Law and Society, Issue 9, Num. 4, pp. $235-241$.

MOHILEVSKYI, Leonid; SEVRUK, Volodymyr; PAVLENKO, Serhii. 2017. "Psycho-Pedagogical Training of Operating Unit Workers of National Police of Ukraine" In: Science and Education, Vol. 164, No. 11, pp. 120132.

MOTUZ, Maksym. 2011. Trends in the development of private detective activity in Ukraine. Available online. In: http://law.knu.ua/images/abook_file/ conf2011_kpp_motuz.pdf. Date of consultation: 19/07/2020.

NYKYFORCHUK, Dmytro; SEVRUK, Volodymyr; PAVLENKO, Serhii. 2017. Detection and investigation of premeditated murders by operative and investigative units of the National Police. Kyiv, Ukraine. National Academy of Internal Affairs.

PAVLENKO, Serhii; SEVRUK, Volodymyr; KOBKO, Yevhen. 2017. "Training police offuicers in the conditions of reforming the system of education of the Ministry of Internal Affairs of Ukraine in accordance with European standards” In: Science and Education, Vol. 164, No. 6, pp. 142-150.

PIDIUKOV, Petro. 2016. "Problems of legalization of private detective activity in Ukraine and the beginning of special training of its subjects" In: Legal Journal of the National Academy of Internal Affairs. Vol. 12, No. 2, pp. $165-177$. 
RAZUMKOV CENTER. 2016. Ukraine 2015-2016: the reform challenge (assessments). Available online. In: https://razumkov.org.ua/uploads/ article/2015-2016_Pidsumky.pdf. Date of consultation: 25/07/2020.

ROGERS, Carl R. 1963. "Learning to Be Free" In Conflict and Creativity: Control of the Mind. Ed. Seymour M. Farber and Robert H. Wilson. New York, EE.UU. McGraw Hill.

SACHAVO, Andrii. 2006. Administrative and legal bases of activity of private security structures and their interaction with internal affairs agencies of Ukraine: monograph. Kyiv, Ukraine. Naukovyi svit.

SARANA, Nadiia. 2014. "Private detectives in Transcarpathia are becoming more popular" In: Mukachevo.net. Available online. In: http:// www.mukachevo.net/ua/news/view/88503. Date of consultation: 19/07/2020.

SOCIOLOGICAL GROUP "RATING". 2012. Law enforcement agencies of Ukraine: trust and assessments of the population, problems of internal security and willingness to cooperate. Available online. In: http:// ratinggroup.ua/ru/research/ukraine/pravoohran_organy_ukrainy_ doverie_i_ocenki_naseleniya_problemy_vnutrenney_bezopasnos_i_ gotovnost_k_s.html. Date of consultation: 22/07/2020.

TAMERYAN, Tatiana; ALIKAEV, Rashid; MUKOVA, Madina; SABANCHIEVA, Asyat; EFENDIEVA, Rosina. 2018. "Prototypical layer of a concept: The english culture type "private detective" In: Amazonia Investiga, Vol. 7, Num. 13, pp. 322-330.

YURKO, Serhii. 2017. Non-state security and law enforcement activities in Ukraine. PhD dissertation. Odesa, Ukraine. National University "Odesa Law Academy".

ZOZULYA, Ihor. 2008. Theory and practice of reforming the system of the Ministry of Internal Affairs of Ukraine: monograph. Kharkiv, Ukraine. Kharkiv Legal. 


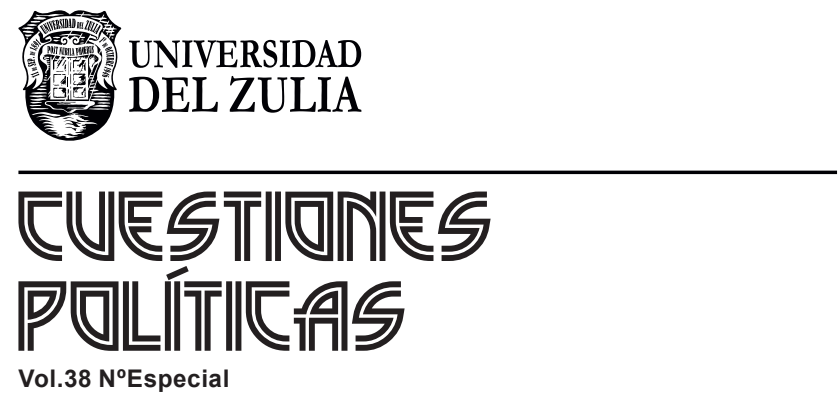

www.luz.edu.ve 